\title{
Beyond a Boundary: Reflections on Newton the Historian, Theologian, and Alchemist
}

\author{
Scott Mandelbrote \\ Peterhouse, University of Cambridge, Cambridge, UK \\ shm24@cam.ac.uk
}

In 1963, the Trinidadian historian C.L.R. James adapted Rudyard Kipling to "pose the question What do they know of cricket who only cricket know? To answer involves ideas as well as facts." ${ }^{11}$ My remarks here relate neither to empire nor to cricket, but to studies of Isaac Newton. Newton himself acted to shape historical commentary on his life and work, which have been the subject of historical study at least since the time of his death. ${ }^{2}$ From the beginning of Newton's public life in the 1670 , access to his working papers became important in forming the reception of his ideas. Newton shared material, often conditionally, while occasionally seeking broader access to information generated by others. Major shifts in the interpretation of Newton's ideas have accompanied significant changes in what was known about his activities and interests.

One such change occurred between the writing of the first of David Brewster's two biographies of Newton (1831) and the second (1855), an interim which unwittingly defined the first great age of Newtonian studies in the history of science. By 1855, Brewster had confronted the substantial witness of unpublished correspondence, biographical memoirs, and working papers held by Newton's descendants. The challenge posed by Francis Baily's Account of the Revd. John Flamsteed (London, 1835) or by Augustus De Morgan's morally critical reading of Newton's personal life encouraged him to search for materials in defence of Newton. Brewster expressed embarrassment, however, concerning Newton's religious opinions: "in the chapter which relates to them I have touched lightly, and unwillingly, on a subject so tender; and in publishing

1 C.L.R. James, Beyond a Boundary (London, 1994 [1963]), xxi.

2 See A. Rupert Hall, Philosophers at War (Cambridge, 1980); Rob Iliffe and Rebekah Higgitt, eds., Early Biographies of Newton, 2 vols. (London, 2006). 
the most interesting of the manuscripts ... I have done little more than submit them to the judgment of the reader." ${ }^{3}$

Embarrassment of a different kind marked Richard S. Westfall's completion of his own biography of Newton. At the climax of the second great age of Newtonian studies in 1980, Westfall revealed the frustration, bordering on neurosis, that he had felt in writing Newton's life: “The more I have studied him, the more Newton has receded from me ... He has become for me wholly other ... Had I known, when in youthful self-confidence I committed myself to the task ... surely I would never have set out." ${ }^{\text {L }}$ Like Brewster, Westfall achieved a triumph. Its character, however, was different. Brewster, despite rejecting Jean-Baptiste Biot's belief that Newton's theological writings were the product of a period of senility, wrote of Newton the theologian or Newton the chemist in compartmentalized terms. He separated these activities from his main narrative of the development and reception of Newton's scientific ideas. ${ }^{5}$ For Westfall, the presentation of Newton as someone whose life was devoted to problem-solving necessitated the incorporation, side-by-side, of all his activities in a single chronological narrative. ${ }^{6}$ Work that Westfall published only after his biography, together with the developing interpretation of Betty Jo Teeter Dobbs, accommodated itself to a more general tendency in the history of science during the 198 os. $^{7}$ This tendency sought to dissolve what were perceived to be artificial boundaries between science and religion, science and magic, or science and pseudo-science, in pursuit of more appropriate actors' categories: "by relating the process of discovery to the cultural environment in which science was prosecuted." 8 The Newton who emerged was someone whose pursuits, in particular in alchemy and theology, were unified and potentially consistent with one another, rather than compartmentalized.

Dobbs expressed this controversial view when she chided Westfall for not having properly achieved "a radical reevaluation of Newton's methodology" and articulated "the conviction that to Newton himself all his diverse studies

3 David Brewster, Memoirs of the Life, Writings and Discoveries of Sir Isaac Newton, 2 vols. (Edinburgh, 1855), 1: vii-xv; Augustus De Morgan, Newton: His Friend: and His Niece, ed. Sophia Elizabeth De Morgan and Arthur Cowper Ranyard (London, 1885).

4 Richard S. Westfall, Never at Rest: A Biography of Isaac Newton (Cambridge, 1983 [1980]), x. I thank Lorraine Daston for information about Westfall's public statements at the time.

5 Brewster, Memoirs, 2: 301-376.

6 See, e.g., Westfall, Never at Rest, 105-106.

7 Richard S. Westfall, "Isaac Newton's Theologiae Gentilis Origines Philosophicae," in The Secular Mind, ed. W. Warren Wagar (New York, 1982), 15-34; Betty Jo Teeter Dobbs, The Janus Faces of Genius: The Role of Alchemy in Newton's Thought (New York, 1991).

8 Charles Webster, From Paracelsus to Newton (Cambridge, 1982), ix. 
constituted a unified plan for obtaining Truth. ${ }^{9}$ Yet Westfall's work depended on forty years of labour by a succession of distinguished editors of Newton's previously unpublished correspondence, mathematical papers, and scientific drafts. ${ }^{10}$ It was not always endorsed by them. "Of course, what makes Newton of interest is not the set of activities that fill the greater part of [Westfall's] biography, but rather the important contributions he made to the fields of mathematics, dynamics and celestial mechanics, and optics." ${ }^{11}$ Leading scholars were reluctant to move with Westfall or Dobbs beyond the boundary established by the editorial criteria that had defined what mattered in Newtonian scholarship in the 195os and 196os. Westfall himself hesitated, in a manner that some might now find surprising. He endorsed the model of Newton as a problem-solver, rather than embracing the idea that he was a "visionary ready to tackle the created world in a bold grab for the whole". ${ }^{2}$

For Floris Cohen, Westfall's total biography represents a final frontier beyond which scholarship about Newton cannot properly advance. Westfall overcame the dichotomy that puzzled his contemporaries and predecessors, between "a rationally sober scientist" and "some magic-tinged and ... allegedly irrational chymist/theologian" (such as the mystical Newton depicted by popularisers like Michael White, who took their cue from John Maynard Keynes' remarks on Newton as "the last of the magicians"). ${ }^{13}$ The three works that prompt this essay are each well over half as long as Westfall's biography. ${ }^{14}$ None of them purports to consider every aspect of Newton's life or studies, and each concentrates on a timeframe representing only part of his active career. Each of them, it should be said at the outset, is a remarkable scholarly achievement. Moreover, the reader should note that any significant criticism raised here

9 Dobbs, Janus Faces of Genius, $10,17$.

10 In particular, A. Rupert and Marie Boas Hall, eds., Unpublished Scientific Papers of Isaac Newton (Cambridge, 1962); I. Bernard Cohen, Introduction to Newton's Principia (Cambridge, 1971); H.W. Turnbull et al., eds., The Correspondence of Isaac Newton, 7 vols. (Cambridge, 1959-1977); D.T. Whiteside, ed., The Mathematical Papers of Isaac Newton, 8 vols. (Cambridge, 1967-1981).

11 I. Bernard Cohen, review of Never at Rest, American Historical Review, 87 (1982), 1353.

12 H. Floris Cohen, "Stock and Bulk in the Latest Newton Scholarship," British Journal for the History of Science, 51 (2018), 687-701, at 689. The term "visionary" does not appear in Never at Rest. Cohen's criticism here of Niccolò Guicciardini, Isaac Newton and Natural Philosophy (London, 2018), only demonstrates that Cohen himself has misunderstood Westfall.

13 Cohen, "Stock and Bulk," 689, 693. Cf. Michael White, Isaac Newton: The Last Sorcerer (London, 1997); John Maynard Keynes, "Newton the Man," in The Royal Society Newton Tercentenary Celebrations, 15-19 July 1946 (Cambridge, 1947), 27-34.

14 I have already reviewed the first of these: Scott Mandelbrote, "Dating the Argonauts," Times Literary Supplement, 5782 (2014), 12. 
might equally be applied to this writer's own, much more insubstantial efforts to address Newton or his works.

These three books rest heavily on a new period of activity in the presentation of Newton's unpublished manuscripts. This has not primarily taken the form of discovery or of the widening of the scope of scholarly editions of Newton's papers. Instead, it has been represented by their collection and representation through the medium of the international digital Newton Project. The endeavours that constitute the Newton Project have provided to everyone working on Newton searchable copies of his writings that now make his manuscripts as accessible as his published work. ${ }^{15}$ Whereas the monumental editorial activity that preceded Westfall's work concentrated on manuscripts that had been deposited in the Cambridge University Library in 1872, the later dispersal of papers retained by Newton's heirs and sold at auction in 1936 formed the initial core of materials tackled by the Newton Project. ${ }^{16}$

Although Westfall went to great lengths to view originals or source microfilm, it is striking that material (then in private hands) that eluded him can still prove revelatory about both Newton's thinking and his working methods. ${ }^{17}$ Comparison of parallel texts regarded as identical by Westfall and Dobbs helps Newman (pp. 92-96) to reveal a trajectory for Newton's alchemy and to demonstrate, for example, that his interest in chymistry predated, and may have prompted, his reading of the work of Robert Boyle in the mid-166os, instead of being derived from Boyle. Newman's analysis of Newton's copying of chymical texts that are otherwise known only in manuscripts made for others alerts us to the fact that the sources of Newton's ideas often remain obscure. Discoveries

15 For these undertakings, see <www.newtonproject.ox.ac.uk $>$ (accessed 25 February 2021) and <https://webapp1.dlib.indiana.edu/newton> (accessed 25 February 2021); see also $<$ https://cudl.lib.cam.ac.uk/collections/newton/1 > (accessed 25 February 2021) and $<$ www .nli.org.il/en/discover/humanities/newton-manuscripts> (accessed 25 February 2021) for presentations of the two largest collections of Newton's manuscripts (at the Cambridge University Library and the National Library of Israel) with metadata, transcriptions, and some translations supplied by the Newton Project. For critical comment, see Niccolò Guicciardini, “Digitizing Isaac Newton," Isis 105 (2014), 403-409 and 827.

16 [H.R. Luard et al.], A Catalogue of the Portsmouth Collection of Books and Papers Written by or Belonging to Sir Isaac Newton (Cambridge, 1888); Sotheby's, Catalogue of the Newton Papers Sold by Order of the Viscount Lymington, [compiled by J.C.C. Taylor] (London, 1936).

17 See William R. Newman, Newton the Alchemist: Science, Enigma, and the Quest for Nature's 'Secret Fire' (Princeton, NJ, 2019), 223-26o, 367-95, 504-508; cf. William Andrews Clark Library, Los Angeles, CA, MS F253L 1693 (one of a number of unpublished letters from Nicolas Fatio de Duillier to Newton that I am currently editing for publication); Sotheby's, Sir Isaac Newton: Highly Important Manuscripts, [compiled by P.R. Quarrie] (New York, 2004), especially pp. 20-21. 
remain to be made. It is not pedantry to assert that our knowledge of the progress of Newton's thought remains provisional, and that this affects our understanding of ideas as well as of facts.

Like Westfall, the authors under consideration here all provide a narrative which is grounded in a chronology of what Newton wrote. Both Buchwald and Feingold, and Newman substantially revise existing treatments of the dating of Newton's interests. Newman not only establishes that the transmutation of metals lay at the heart of Newton's entire practice of chymistry but also shows that his alchemical interests both began earlier and ended later in his career than others have suggested. In the process, he constructs some relationships (notably through Newton's reading of Boyle, Descartes, and Hooke in the 166os and 1670s) and deconstructs others (for example, between his earlier chymical and later physical theories of light). Buchwald and Feingold push back against the belief that Newton's writings on chronology, based on astronomical calculation rather than a reliance on textual records, should be seen as being of a piece with his interests in heathen mythology in the 168os. What they write at times sits oddly with Iliffe's account of Newton's religion.

For both Iliffe and Buchwald and Feingold, Newton's writings of the 169os represent a turning point in his attitude to the authority of text and testimony. To Iliffe (pp. 156-188, 315-389), what Newton then wrote on religion was the culmination of a journey to heresy, based on the development of a sceptical attitude to texts born out of an almost pathological rejection of the errors of Roman Catholicism. For this account, the forensic exposure of the theological fraud supposedly perpetrated by Athanasius in the fourth-century creation of the doctrine of the Trinity represented a crucial step. It enabled both Newton's critical deconstruction of the alleged corruption of the text of the New Testament and his eventual presentation of the fulfilment of apocalyptic prophecy. In this context, the litigation in which Newton was engaged, first in a private capacity both in disputes of natural philosophy and in matters of private property, later in public on behalf of the University of Cambridge and eventually in his role targeting counterfeiters as Warden of the Mint, demonstrated behavioural continuity between Newton's personal life and his textual activity. For Buchwald and Feingold (pp. 222-245), by contrast, the forensic training that Newton received through his prosecution of coiners and clippers in the 169 os was what made him sceptical of historical testimony derived from written sources and pushed him decisively towards the evidence of the past that could be confirmed from astronomical data. Athanasius does not even figure in their index. Whereas Buchwald and Feingold place the most important thinking that Newton did about the chronology of the ancient world after the mid-169os, Iliffe's story of Newton's "religious worlds" effectively ends at 
that point. Yet both works in practice describe topics, on which Newton was engaged in writing during the 1710 s and 1720 s, and that emerged in public only through books posthumously compiled by his executors and published, respectively, in 1728 and $1733 .{ }^{18}$ The book which made Newton's writings on the fulfilment of prophecy known to a broader public in 1733 is mentioned by Iliffe only in a footnote (p. 403).

Decisions made by past editors of Newton lie at the heart of the problem of dating, alongside the chronology that they, with Westfall, established for Newton's writings. These dates were based largely on judgements of the development of Newton's handwriting. Efforts have been made to improve them by consideration of the dating of watermarks in Newton's papers, but these have fallen foul of difficulties caused by Newton's indiscriminate use and reuse of paper and by the fact that the date ranges for paper produced by the largest manufacturers cannot themselves be determined precisely. ${ }^{19}$ Yet, for any narrative account, dates do matter. For instance, several scholars have noted the use of the work of the Oratorian critic Richard Simon in Newton's "Historical Account of Two Notable Corruptions of Scripture," written initially as a letter to a friend (John Locke) and sent in November 169o. Iliffe (pp. 371, 375-376) now writes both that "Newton had probably not read Simon's work when he sent the initial version to Locke" and that "it is possible that Newton read [Simon's work] in order to produce his initial analysis for Locke, although he made no reference to it." ${ }^{20}$ In fact, there is no need for equivocation. All of Newton's references to Simon in the surviving draft of his letter to Locke were later additions, and his encounter with Simon's Critical History of the Text of the New Testament (1689) followed a recommendation made to him via Locke

18 On the composition of Newton's Chronology of Ancient Kingdoms Amended (London, 1728) and Observations upon the Prophecies of Daniel and the Apocalypse of St. John (London, 1733), see Cornelis J. Schilt, "Of Manuscripts and Men: The Editorial History of Isaac Newton's Chronology and Observations," Notes and Records of the Royal Society, 74 (2020), 387-408, <https://doi.org/10.1098/rsnr.2018.oo69>, accessed 25 February 2021.

19 Alan E. Shapiro, "Beyond the Dating Game: Watermark Clusters and the Composition of Newton's Opticks," in The Investigation of Difficult Things, ed. Peter M. Harman and Alan E. Shapiro (Cambridge, 1992), 181-227. The dates currently used by the Newton Project derive in most cases from the work of Westfall, as modified by Shapiro.

20 Justin Champion, “Acceptable to inquisitive men': Some Simonian Contexts for Newton's Biblical Criticism, 1680-1692," in Newton and Religion, ed. James E. Force and Richard H. Popkin (Dordrecht, 1999), 77-96; Rob Iliffe, "Friendly Criticism: Richard Simon, John Locke, Isaac Newton and the Johannine Comma," in Scripture and Scholarship in Early Modern England, ed. Ariel Hessayon and Nicholas Keene (Aldershot, 2006), 137-157. 
by Jean Le Clerc in April $1691 .{ }^{21}$ If Newton's sceptical approach to the text of the New Testament had sources, those sources must be found in reading that was completed before autumn 169o. Whereas Westfall associated Newton's religious heterodoxy with a form of proto-deism, Iliffe (pp. 365-368) places it in the context of the breaking debate about Unitarianism, embodied in the anti-Athanasian publications of Stephen Nye and of the Oxonian, Arthur Bury. These were books that John Locke owned, but which did not figure in Newton's library. ${ }^{22}$ On the other hand, an author whom Newton undoubtedly did read was Ralph Cudworth. Newton's interest in Cudworth has normally and correctly been presented with reference to his attitudes about a pre-Christian tradition of ancient wisdom. Yet (as Iliffe recognises, 137-138) Cudworth's writings raised the question of when and how the doctrine of the Trinity came to be used in the early Church, through consideration of the same patristic evidence that Newton would explore in the 169 os. $^{23}$

To take a more complex example: a manuscript headed "De motu Corporum Liber Secundus" is mostly written in the hand of Newton's amanuensis, Humphrey Newton. It represents a draft for an early stage of the Principia (1687). It was composed during the mid-168os and is related to another manuscript that Newton deposited at Cambridge in Michaelmas Term 1687 as evidence of his lecturing. ${ }^{24}$ According to Westfall (p. 434), "Newton chose to open [its] argument with a passage taken directly from his 'Origins of Gentile Theology'” Iliffe (p. 200) disagrees: "There is nothing in this text [Theologiae Gentilis Origines Philosophicae] that betrays any awareness of the doctrines in the Principia, while it also omits any reference either to the supra-lunary orbit of comets, or to the Copernican relevance of the vestal religion - both of which are in the introduction to the liber secundus'." At a technical level, Westfall is misleading. The opening phrases of the "Liber Secundus" cannot be found

21 For the original text, see New College, Oxford, Ms 361/4; see also E.S. de Beer, ed., The Correspondence of John Locke, 8 vols. (Oxford, 1976-1989), 4: 248.

22 See, respectively, John Harrison and Peter Laslett, The Library of John Locke (Oxford, 1965); John Harrison, The Library of Isaac Newton (Cambridge, 1978).

23 See William Andrews Clark Library, Ms fN563Z, fols. 1r-2r; Trinity College, Cambridge, MS R.16.38A, fol. 436r; "Newton's Out of Cudworth," in James E. Force and Richard H. Popkin, Essays on the Context, Nature, and Influence of Isaac Newton's Theology (Dordrecht, 199o), 207-213; Danton B. Sailor, "Newton's Debt to Cudworth," Journal of the History of Ideas, 49 (1988), 511-518. Citations from the work of Samuel Bochart (Trinity College, shelfmark NQ.8.27) suggest a date no earlier than the mid-168os for Newton's notes (although a date in the 169 os is also possible). Newton did not own a copy of Cudworth's True Intellectual System of the Universe (London, 1678), but the author gave one to Trinity (eventually disposed of as a duplicate in 1784 ).

Cambridge University Library, Ms Add. 399o; cf. Ms Dd. 4.18. 
in the manuscript from whose heading Westfall derived the title Theologiae Gentilis Origines Philosophicae. ${ }^{25}$ Yet Iliffe's claim that the manuscripts constitute two "separate but related" projects is also problematic. The opening section of the "Liber Secundus" in Humphrey Newton's hand paraphrases (and the accompanying marginal note in Newton's own hand refers to sources given on) a particular page of a particular book. ${ }^{26}$ Newton had that book open on his desk throughout the composition of what is now called the "Origines". Moreover, ancient knowledge of Copernican astronomy is mentioned explicitly elsewhere in materials that contain both drafts for the "Origines" and what are properly later elaborations on its arguments. ${ }^{27} \mathrm{Iliffe}$ (pp. 201-203, 437) may well be right - and Buchwald and Feingold (pp. 143-163) would agree - that these passages in fact derive from a subsequent stage in Newton's thinking, linked to conversations with David Gregory in 1694 and to the revision of the Principia rather than to its composition. Certainly, Newton expanded his work on both classical and Christian sources for the religion and philosophy of antiquity at that time. Yet other difficulties remain about the claim that the Origines and the "Liber Secundus" were "separate but related".

Iliffe's argument provides a key example of the most important way in which he, Buchwald and Feingold, and Newman present a new view of Newton. All three books agree in disaggregating what Westfall and, above all, Dobbs had brought together: in this case, the celestial mechanics of the Principia and Newton's reading on the ancients' worship of the stars, to which could be added his interest in the use of ancient mythology by alchemical authors. As Newman points out (pp. 57-62, echoing Buchwald and Feingold, pp. 147-148), the decoding of alchemical symbolism was neither an exercise in the writing of religious history nor a meaningful contribution to the history of astronomy. Instead, these "were separate areas of endeavor with their own distinct hermeneutical methods and goals." For Buchwald and Feingold (pp. 32-106, 166-194), Newton's work was marked by methodological consistency, in particular by the use of approximation and repeated averaging to overcome uncertainties in data provided by the senses through the practice of mathematics. Their account of this ranges from Newton's earliest astronomical observations, through his controversial engagements over the behaviour of light, to the discovery of his method of working with regnal years and historical generations in

25 National Library of Israel, Jerusalem, ms Yahuda 16.2.

26 Gerardus Joannes Vossius, De theologia gentili et physiologia Christiana (Amsterdam, 1641); Newton's copy (Trinity College, shelfmark NQ. 8.46(2)) has the relevant passage marked by a dog-ear at p. 311 .

27 MS Yahuda 17.2, fols. 18r-19r (on the Copernicanism of Orpheus and on Egyptian and classical belief in comets as a form of supra-lunary planet). 
chronology. They argue (p. 434) that Newton's chronological studies were essentially independent of his writing of theology: "The Chronology proper should be viewed, fundamentally, as a contribution to secular historical scholarship: an attempt to establish a new chronological system, within the confines of the Masoretic time line, upon which a universal history might be erected." Newton the historian was therefore distinct from Newton the interpreter of prophecy and, in both cases, the divergence of Newton's ideas from established norms was derived principally from the results of unremitting scholarly practice.

In this respect, what Buchwald and Feingold write is hard to reconcile with the view of Iliffe (and older scholarship) that Newton's interpretation of prophecy was bound up with his heterodox conclusions about the early Church. It may be possible to square the circle by remembering that Newton's writings were private interpretations, not doctrinal statements, which had no apparent impact on his public religious behaviour (such as that was). Heterodoxy in scholarship was a judgement to be made by the reader, rather than a conscious choice by the author, as reactions to the writings of Cambridge professors such as Cudworth or John Spencer showed. Nevertheless, it is difficult to concur entirely with the depiction of Newton the scholar at work behind Chinese walls, carefully keeping separate activities that later historians would place in one category or another of his thought. The evidence of Newton's books does suggest that only some work made it into his laboratory, although it also makes a strong case for alchemical research going on in Newton's study as well as at his furnace. ${ }^{28}$ By contrast, the same evidence suggests that what was grist to Newton's mill when writing "chronology" might also have been encountered when thinking about ancient religion or even when considering Old Testament prophecy. ${ }^{29}$

The real problem, however, lies in the assumption that it is straightforward to identify distinct pieces of work that Newton was engaged in at particular times. The notion that one could separate out particular clusters from Newton's

28 For example, Trinity College, shelfmark NQ.10.145 (Ars Chemica (Strasbourg, 1566)), shows Newton annotating in red pencil, possibly in the laboratory, later inking over some annotations, still later copying out a translation made from the text into a florilegium kept as a paper booklet (see King's College, Cambridge, Ms Keynes 27, fols. 4V-12r).

29 An example here is Newton's use of another secular chronologist, John Marsham. Marsham's Chronicus Canon Egyptiacus (Leipzig, 1676) was cited in passages written by Humphrey Newton in Yahuda Ms 16.2. It informed the key identification of Sesostris and Sesac deployed in Newton's published Chronology. Marsham also appeared in passages discussing the four monarchies as a prelude to the interpretation of prophecy (e.g. Yahuda Ms 7.1, fol. 1r), which, even if they may have been misplaced in Newton's manuscripts, draw attention to the fact that work might have been undertaken on the same page as well as at the same time on parallel projects. 
manuscripts and treat them as a simple draft for publication is at least as old as Brewster. ${ }^{30}$ It pervades philosophical discussion of Newton's writings, not least because of the significance within that genre of the contents of one notebook, "De Gravitatione". ${ }^{31}$ Both Westfall and Dobbs relied on the identification of key manuscripts to which they assigned names. ${ }^{32}$ Thanks to Westfall, all discussion of Newton's writing about religion hinges to some extent on the so-called Origines. Yet that manuscript contains materials demonstrably written by multiple hands over a period of five to ten years. Its contents are not consistent, and papers related to it can be found in many places, widely dispersed not least by the twentieth-century trade in Newton's manuscripts. ${ }^{33}$ At one point, Newton labelled some of this material with the title that Westfall gave it, but we simply do not know whether or for how long he thought of it as having a particular content or structure. A striking example in the same vein is the large manuscript sometimes called "Of the Church" that Westfall was unable to consult. It too has been written about as if it constituted a single, coherent work. ${ }^{34}$ Examination of the manuscript and its relationship to Newton's other writings provides reasons to question this belief. The simplest of these is that the opening bifolium which is headed "Of the Church" is separate both in codicological terms and in form and content from the bulk of the rest of the manuscript. Newton's "Of the Church" in its current form is the creation of the bookseller Gabriel Wells, who bought lot 249 in 1936 and subsequently divided it. Lot 249, however, was itself put together by John and Catherine Conduitt and those whom they employed to create publishable books out of Newton's papers. It was identified by J.C.C. Taylor, the compiler of the ${ }^{1936}$ sale catalogue, with a manuscript described in Catherine Conduitt's will as "A Church History Compleat". ${ }^{35}$ Like the Chronology or the Observations, "Of the Church" is an invention of the earliest phase of the Newton industry as much

$30 \quad$ For example, the discussion of "Paradoxical Questions concerning ... Athanasius" (now mostly William Andrews Clark Library, Ms ${ }^{* *} \mathrm{~N}_{5} 63 \mathrm{M}_{3} \mathrm{P} 222$ ) or "Irenicum" (King's College, Ms Keynes 3), in Brewster, Memoirs, 2: 342-347.

31 Cambridge University Library, Ms Add. 4003.

32 For an earlier warning about such practice, see William Newman, "Newton's Clavis as Starkey's Key," Isis 78 (1987), 564-574.

33 Westfall recognised most of this: "Isaac Newton's Theologiae Gentilis Origines Philosophicae," $16-17$.

34 Matt Goldish, "Newton's Of the Church: Its Contents and Implications," in Newton and Religion, ed. Force and Popkin, 145-164; Steffen Ducheyne, "Isaac Newton's 'Of the Church," European Journal of Science and Theology, 5 (2009), 25-35.

35 Cologny, Fondation Martin Bodmer, Newton ms, especially fols. 1-6 ("Introduction and Table of Contents"); cf. Sotheby's, Catalogue of the Newton Papers, 69-71, and Yahuda MS 15 . 
as it is a work by Newton. This is also true of a manuscript discussed above, which was in fact published in 1728 , "De motu Corporum Liber Secundus". The binding of that manuscript, its labelling by Thomas Pellet and others, and its current form and structure are a product of the editorial strategies of the Conduitts, rather than of Newton himself. ${ }^{36}$ Moreover, regardless of what he may have written in the so-called Origines, Humphrey Newton in this manuscript copied out Newton's thinking, paraphrasing Vossius, about ancient ideas of the heavens, and his interpretation of those ideas in Copernican and antiCartesian terms. That Newton may have developed this line of thought later in conversation with David Gregory is indisputable, but that he was already thinking it in the mid-168os is also clear. The cramped additions that Newton made to the second folio of the manuscript, moreover, show the extent to which he very soon began to revise and reorder his ideas.

The point of these reflections is not to make the absurd claim that we cannot know what Newton thought or when he thought it. Instead, it is to bring home how difficult the task is and to caution against erecting obstacles to it by creating stages to Newton's thinking that did not exist. Even Newton cannot have held every intellectual problem that concerned him in his mind at the same time. Nevertheless, it is important to realise that the compartmentalization of Newton's writings is a process that began in earnest after his death, rather than before it. In the 168os and 169os, Newton thought that what he had discovered about ancient mythology belonged in some way with what he had discovered about the natural world. He believed that a book written by an Arminian theologian and ecclesiastical historian could contribute to an understanding of the solar system. He later retreated from that position. By then, he had read much of the patristic literature for knowledge of which he had earlier relied on Vossius, and he used that to transform what he had written before ca. 1680 on the fulfilment of prophecy by developing a much fuller understanding of the early Christian Church. In the process, he found new uses for the chronological canon of Sir John Marsham, whose ideas he advanced using astronomical as well as textual evidence. In all these activities, Newton's engagement with evidence and with problems was dynamic. Writing was a way to reach solutions, a process rather than an end in itself, as demonstrated by the manuscript tools that Newton created to help him in his laboratory. As Newman shows in his treatment of the transformative effect of Michael Sendivogius or Edmund Dickinson on Newton's alchemy, the effort to

36 Isaac Newton, De Mundi systemate liber (London, 1728); Cohen, Introduction, 110-112, discusses the posthumous circulation of copies of the manuscript among Newton's followers. 
take possession of what he had read gave as much impetus to his work as did experiment or calculation.

Buchwald and Feingold, Iliffe, and Newman are all conscious of such limitations, and more aware of them than previous writers on Newton. Nevertheless, their stress on disconnectedness does not always acknowledge the implications that derive from continuities in Newton's working habits. ${ }^{37}$ One surprising continuity, to which Newman draws attention in his revelatory treatment of Newton's alchemical relationship with Nicolas Fatio de Duillier and in his discussion of Newton's improbable collaboration with William Yworth, is the extent to which Newton did not work alone.

Much of what we know about the chronology of Newton's work, for example, the dates added in margins or squeezed between lines in the "Waste Book", derives from the fact that Newton shared his work (and not just his correspondence) with others, both before and after priority became controversial. Closer attention to copies made of Newton's mathematical papers by William Jones, John Colson, or Charles Morgan might enrich our understanding of the development of Newtonian mathematics in the early eighteenth century, in the same way that Newman has enhanced our knowledge of Newton's alchemy in the 169os. Earlier copies of some material exist, spreading from papers which Newton supplied to John Collins. ${ }^{38}$ Martin Folkes, one of a coterie of Clare College Newtonians, was chosen by Conduitt to edit Newton's Chronology not only because of his role as Vice-President of the Royal Society and his friendship with the author. Folkes had already been involved in the manuscript circulation of the abstract of the work that would be published as the "Short Chronicle". He had even lent his own copy to Newton, who had himself emended it. ${ }^{39}$ The perception that has existed, since the time of Baily, of Newton's unwillingness to collaborate with others may to some extent be misleading (indeed, Buchwald and Feingold (pp. 268-271) explore how important to Newton was his relationship with Flamsteed and how difficult Flamsteed had proved to work with).

The competition between Fatio and David Gregory over who might contribute most to the revision of the Principia in the early 169os, the interest of Archibald Pitcairne in putting the Opticks into Latin, or the role of William

37 This claim is related to, but not quite the same as, Buchwald and Feingold's championing of a life-long Newtonian "style" of thinking, cf. Newton and the Origin of Civilization, 4-5, and I. Bernard Cohen, The Newtonian Revolution (Cambridge, 1980), especially xii-xiv.

38 These sentences rely on work in progress by the author and Niccolò Guicciardini, principally on the Macclesfield Collection of Newton papers now in the Cambridge University Library.

Bibliothèque d'agglomération du Pays, Saint-Omer, Ms 786. 
Jones, George Cheyne, and John Keill in the dissemination of the calculus all reveal Newton's ability and willingness to co-opt others to his projects over sustained periods of time, even if none of these relationships proved so productive in print as those that Newton maintained with Edmond Halley, Samuel Clarke, or Roger Cotes. ${ }^{40}$ Through his friendship with John Covel, Newton participated in the theological research of John Mill and Johann Ernst Grabe, while he elsewhere discussed manuscripts of the New Testament with his new ally, Locke. ${ }^{41}$ Even the most hermetic environment for Newton's work, his laboratory, figured on the tourist trail for visitors to Cambridge in the 169 os.

The diary of Andreas Adam Hochstetter for April 1691 provides an unlikely way to draw together some of the strands of these reflections and one which has so far escaped the attention of Newton scholarship. ${ }^{42}$ Hochstetter (16681717) studied at the Lutheran seminary in Tübingen and travelled in England from August 169o to April 1691, as part of a much longer academic journey with his fellow student, Johann Gottfried Hoffmann. He met many English scholars and in Cambridge circulated with several of those whom Newton knew most intimately and by whose ideas he was most influenced. These included Spencer (with whom Hochstetter discussed Marsham's chronology) and Covel (with whom Hochstetter discussed biblical manuscripts and the theology of the Orthodox Church). Through Otto Mencke, Hochstetter had an introduction to Newton, and he called on him on six occasions between 4 and 13 April.43 The detail that Hochstetter's diary provides about those meetings is unusual, but there is little reason otherwise to see them as different from a succession of other contacts between Newton and visiting scholars in Cambridge or London, about which we know from correspondence, published accounts, or even the presence of Newton's signature in alba amicorum. ${ }^{44}$ Hochstetter was preceded,

$40 \quad$ Cf. Cohen, Introduction, 162-199.

41 The Queen's College, Oxford, Ms 326, fols. 2r-4v; Bodleian Library, Oxford, Ms Grabe 36; Russian Archive of Ancient Acts, Moscow, RGADA.F.16o7 Dresden Ms Op. 1 M. 13.

42 But see George Gömöri and Stephen D. Snobelen, "What he may seem to the world: Isaac Newton's Autograph Book Epigrams," Notes and Records of the Royal Society, 74 (2020), 409-452, and its supplement: "The Peregrinations of Isaac Newton's Autograph Seekers," available at: <https://royalsocietypublishing.org/doi/suppl/10.1098/rsnr.2020.0oo6>, accessed 2 March 2021). I alerted Gömöri and Snobelen to Hochstetter's diary (which I first consulted in 2003). My reading of the diary (which is tightly bound and in places hard to decipher) differs in some essentials from theirs.

43 Württembergische Landesbibliothek, Stuttgart, Ms Cod. Hist. Oct. 8 (diary of Andreas Adam Hochstetter), fols. 296r-313r.

44 For accounts of such visits, see Martin Mulsow, "Orientalistik im Kontext der sozinianischen und deistischen Debatten um 170o," Scientia Poetica, 2 (1998), 27-57; Gömöri and Snobelen, "Peregrinations." 
for example, by the Hebraist Johann Andreas Danz (1654-1727), who also met Spencer and Newton when he came to Cambridge (as well as Cudworth, Henry More, and Edmund Castell, all of whom had died by 1691). On his way through Jena in May 1689, Hochstetter called on Danz, and his subsequent itinerary overlapped at times with visits that the older scholar had made. ${ }^{45}$ Hochstetter's published account of his journey to England, like the briefer description in print of Danz's time in England, concentrated on the libraries, books, and manuscripts that people had shown him. The published account barely mentioned Newton, and only in passing, and certainly gave no idea of the extent to which Newton shared information with his visitor. ${ }^{46}$

At 11 a.m. on 6 April, Newton met Hochstetter in his study at Trinity. He took him into his garden and his laboratory, where a furnace burned perpetually from 7 a.m. until midnight, and he showed him some rare minerals. The two scholars discussed Halley's astronomical discoveries on St Helena, the telescopes of Hevelius and the increased accuracy of celestial observations since the time of Tycho Brahe, moving on to the astronomy of Jeremiah Horrocks and Flamsteed's elaboration of his lunar theory, and the discovery by Cassini of Saturn's satellites. Newton then turned to the quarrelsomeness of theologians, mentioning the attempt by Gisbertus Voetius to suppress the Cartesians, and Hochstetter asked whether theologians or mathematicians could best understand the natural world. Newton recounted his controversy with the Jesuit, Linus (Francis Hall), and its revival by Anthony Lucas. He told Hochstetter the story of Lucas' treachery in altering correspondence of which the originals had been lost in a fire in Newton's study. ${ }^{47}$ Finally, Newton and Hochstetter discussed the relative merits of the treatments of ancient weights and measures given by Edward Bernard, Savilian professor at Oxford, and Richard Cumberland, before closing by considering the usefulness of Arabic for an understanding of Archimedes and other authors. ${ }^{48}$

45 Society of Antiquaries, London, Ms 439, fol. 159r (Danz's entry in Hochstetter's album amicorum: I thank George Gömöri for alerting me to this); cf. Johann Franz Budde, Ad Lectiones cursorias, quas vocant, et disputationem inauguralem ... Io. Andreae Danzii ... invitat (Jena, 1710), sig. d2r-v.

46 Andreas Adam Hochstetter, Oratio de utilitate peregrinationis anglicanae (Tübingen, 1697), 32-33.

47 Iliffe, Priest of Nature, 159-166, describes the role of Linus and Lucas in forging Newton's anti-Catholicism.

48 Bernard's work appeared initially as an appendix to Edward Pococke, A Commentary on the Prophecy of Hosea (Oxford, 1685); a second edition, with additional material by Nicolas Fatio de Duillier and Thomas Hyde, was published as De Mensuris et ponderibus antiquis (Oxford, 1688); cf. Richard Cumberland, An Essay towards the Recovery of the Jewish Measures \& Weights (London, 1686). Newton owned all three books, and was given 
On 9 April, Hochstetter and Newton again met at Trinity. Newton showed Hochstetter his reflecting telescope and talked about how to understand biblical texts regarding the motion of the earth and the stability of the sun. Here, Hochstetter's account appears directly to paraphrase what Newton wrote about "the Scriptures speaking not in the language of Astronomers ... but in that of [th]e common people" in a brief manuscript headed "An Account of the Systeme of the World described in Mr Newton's Mathematicall Principles of Philosophy."49 Both that text and Hochstetter's diary consider passages about the immovability of the globe derived from the Book of Job, the Psalms, and the Second Epistle of Peter (but also from Strabo), whose purpose, Newton argued, was to show that the inhabited world after the Deluge was not a floating island, and that God had fixed the known continents in a single, surrounding sea (which the ancients all called the Atlantic Ocean, but which Hochstetter knew simply as "the German sea"). Newton told Hochstetter that this was the context in which to interpret biblical references to the stars, and even the sun, sinking down into the sea, as if they were going to bed..$^{50}$ Finally, Newton remarked on the death of the learned and industrious geo-heliocentric astronomer, Giovanni Battista Riccioli (1598-1671). ${ }^{51}$

In later visits to Newton, on 11 and 12 April (Easter Sunday), Hochstetter discussed the structure of the English state since 1662, the role of parliament, the royal supremacy in the Church, and the deposition of James II. Newton

the second edition of De Mensuris by Bernard himself (Harrison, Library of Isaac Newton, 99, 127, 219).

49 Cambridge University Library, MS Add. 4005, fols. 39r-42r: the second half of this manuscript addresses Hochstetter's question of 6 April. On this manuscript, see I. Bernard Cohen, "Isaac Newton's Principia, the Scriptures, and the Divine Providence," in Philosophy, Science, and Method, ed. Sidney Morgenbesser, Patrick Suppes and Morton White (New York, 1969), 523-548 (dating it to the early 169 os, perhaps to 1693 ); Stephen D. Snobelen, “Not in the Language of the Astronomers': Isaac Newton, the Scriptures, and the Hermeneutics of Accommodation," in Nature and Scripture in the Abrahamic Religions: Up to 1700, ed. Jitse M. van der Meer and Scott Mandelbrote, 2 vols. (Leiden, 2008), 2: 491-530.

50 Württembergische Landesbibliothek, Ms Cod. Hist. Oct. 8, fol. 306r-v; cf. Cambridge University Library Ms Add. 4005, fols. 39r-4or. Particularly striking is the coincidence in both places of the discussion of the earth as a floating island and the similarity between Hochstetter's account ("Sanè et in eâ opinione sacrae scripturae putat Isaacus Newtonus quod stellae in marè occumbant, et sol ipse, cubiliumque veluti procedant ...") and an addition Newton made to his manuscript: "\& this earth \& sea they accounted flat as if [th]e sun moon \& stars ascended out of [th]e ocean at their rising \& went down into it again at their setting."

51 Newton owned a copy of Riccioli's Almagestum novum (Bologna, 1651), see Harrison, Library of Isaac Newton, 227. 
recommended John Rushworth's Historical Collections as a source for parliamentary history, and described parliamentary opposition to alliance with Catholic Spain under James I and Charles I, and the inadequacy of the doctrine of the divine right of kings. ${ }^{52}$ Eventually, on 13 April, Hochstetter took his leave of Newton, with whom he talked about Descartes and about whether the late upheavals in England had largely been caused by the clergy.

It is for the reader to decide what this example tells us about the connectedness of his various pursuits in Newton's own mind. Clearly, they were connected in his conversation, and not just in discussions that he had with people whom historians have tended to classify as his favoured friends, such as David Gregory. We now have three magnificent new works of scholarship which extend our grasp of Newton's expertise in many directions. In terms of our knowledge of the facts of Newton's life, each of them pushes back the boundary. The ideas that lie behind them and that we can draw out of them also redraw the field. Even so, as scholars realised as early as the 183os, and as these books in different ways now demonstrate, to know Newton properly, we need to conceive of a world beyond him, rather than remaining, however understandably, overawed by what he achieved.

$5^{2}$ At his death, Newton's library included the eight-volume edition of Rushworth's Historical Collections of Private Passages of State, Weighty Matters in Law, Remarkable Proceedings in Five Parliaments (London, 1721); see Harrison, Library of Isaac Newton, 23o. When he met Hochstetter, however, only the first two parts, describing events from 1618 to 1640, had been published (volume 1 in 1659 [reprinted in 1682]; volumes 2-3 in 1680 [reprinted in 1686]). 